\title{
Environmental changes and zooplankton temporal and spatial variation in a disturbed brazilian coastal lagoon
}

\author{
Branco, CWC. ${ }^{\text {** }}$, Kozlowsky-Suzuki, B. ${ }^{\mathrm{a}}$ and Esteves, FA. ${ }^{\mathrm{b}}$ \\ a Departamento de Ciências Naturais, Universidade Federal do Estado do Rio de Janeiro - UNIRIO, \\ Av. Pasteur, 458, CEP 22290-140, Rio de Janeiro, Brazil

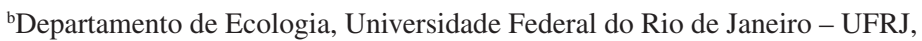 \\ CP 68020, CEP 21940-540, Rio de Janeiro, RJ, Brazil \\ *e-mail: cbranco@unirio.br
}

Received July 6, 2005 - Accepted November 8, 2005 - Distributed May 31, 2007

(With 5 figures)

\begin{abstract}
The Imboassica lagoon, located in the Municipality of Macaé (RJ), is separated from the sea by a sand bar, and its surroundings are partially occupied by residential areas. This coastal lagoon has undergone environmental degradation due to sewage input and artificial sand bar openings. The temporal and spatial variation of environmental variables and zooplankton were studied monthly for four years. There were five artificial openings of the sand bar during the period of study, mostly in the rainy season. Besides osmotic changes, these events caused the drainage of the water of the lagoon into the sea, loss of total organic nitrogen, and an increase of total phosphorus. The zooplankton community of Imboassica lagoon included freshwater and marine taxa, holoplanktonic, meroplanktonic and nectobenthonic forms. Polychaeta, Bivalvia and Gastropoda larvae, and the taxa of Rotifera Hexarthra spp., Lecane bulla, Synchaeta bicornis, nauplii of Cyclopoida and Calanoida copepods were considered constant taxa. Distinct zooplankton assemblages were found during zooplankton spatial surveys in oligohaline and mesohaline conditions. The successful zooplankton populations were either favored by the disturbance of the sand bar opening, such as the veligers of the gastropod Heleobia australis, or capable of fast recovery after the closing of the sand bar, during the succession from a marine into an oligohaline environment, such as Hexarthra spp.. Such populations seemed well adapted to the stress conditions usually found in the lagoon due to osmotic changes, column mixing, nutrient input, and high fish predation pressure. Rare species in the community, such as Moina minuta, presented population increases all over the lagoon under oligohaline conditions.
\end{abstract}

Keywords: zooplankton community, coastal lagoon, sand bar opening, Hexarthra spp., Moina minuta.

\section{Mudanças ambientais e variação temporal e especial do zooplâncton em uma lagoa costeira brasileira submetida a distúrbios}

\begin{abstract}
Resumo
A Lagoa Imboassica, localizada no Município de Macaé (RJ), é separada do mar por uma barra de areia e se encontra cercada parcialmente por áreas residenciais. Esta lagoa costeira tem sofrido intensa degradação ambiental devido à afluência de esgotos domésticos e a aberturas artificiais da barra de areia. Neste estudo foram acompanhadas, mensalmente ao longo de quatro anos, as variações temporais e espaciais de variáveis ambientais e do zooplâncton. Durante o período estudado foram realizadas cinco aberturas artificiais da barra de areia, sendo a maioria efetuada na época chuvosa. Além das alterações osmóticas, estas aberturas causaram a drenagem da água da lagoa para o mar, diminuição dos valores de nitrogênio total e aumento da concentração de fósforo total. A comunidade zooplanctônica da lagoa incluiu táxons de água doce e marinhos e formas holoplanctônicas, meroplanctônicas e nectobentônicas. Foram considerados constantes na comunidade larvas de Polychaeta, Bivalvia e Gastropoda, os táxons de Rotifera Hexarthra spp., Lecane bulla, Synchaeta bicornis e naúplios de copépodos Cyclopoida e Calanoida. Durante as amostragens espaciais ao longo de todo o corpo da lagoa em condições oligohalinas e mesohalinas foram encontradas distintas assembléias zooplanctônicas. As populações zooplanctônicas que apresentaram maior ocorrência foram aquelas aparentemente favorecidas pelo distúrbio causado pelas aberturas de barra, tais como véligers do gastrópode Heleobia australis, ou capazes de recuperação rápida após o fechamento da barra de areia, durante a transição de um ambiente marinho para um oligohalino, como Hexarthra spp.. Tais populações se mostraram bem adaptadas às condições de "stress" usualmente encontradas na lagoa devido a mudanças osmóticas, mistura da coluna d'água, aporte contínuo de nutrientes e alta pressão de predação por peixes. As espécies consideradas como raras na comunidade zooplanctônica, como Moina minuta apresentaram maiores densidades ao longo de toda a lagoa em condições oligohalinas.
\end{abstract}

Palavras-chave: comunidade zooplanctônica, lagoa costeira, abertura da barra, Hexarthra spp., Moina minuta. 


\section{Introduction}

Numerous human nuclei have been established along the Brazilian coast, and the last three decades have been characterized by great urban expansion along the coastal areas and by an increase of anthropogenic effects on their aquatic ecosystems. The human impacts on the Brazilian coastal lagoons can be summarized by two types: the land filling of natural wetlands as a consequence of the construction of villages, and the direct input of urban drainage, especially sewage, into the water of the lagoons. The eutrophication process remains the most important recognized problem in most of the Brazilian urban coastal lagoons, as well as throughout the world, since they are regions of restricted exchanges with the adjacent ocean and accumulate nutrients from the surrounding watershed (Pereira et al., 2002; Newton et al., 2003).

The main tool used to improve the water quality and fishing activities or to control the water level of the Brazilian coastal lagoons has been the management of the connection with the sea. As the construction and maintenance of channels are very expensive and can only be afforded by large Municipalities, the artificial sand bar opening has been the most widely-used procedure, which causes disturbance to the lagoon ecosystems. The sand bar openings cause radical alteration of the physical and chemical conditions including drastic reduction of water volume, perishing of freshwater communities transported to the sea, passive and active entrance of marine species into the lagoon, and osmotic stress to freshwater, brackish, and marine species (Aguiaro and Caramaschi, 1995; Suzuki et al., 2002).

Imboassica lagoon is a good example of a Brazilian coastal lagoon, in which human intervention has been responsible for its environmental degradation due to sewage input and artificial sand bar openings. This research aimed at studying the environmental changes and relating these changes to the temporal and spatial variations of the zooplankton community. Zooplankton constitutes a sensitive tool for monitoring environmental changes in coastal lagoons because the populations react immediately to variations in trophic status and salinity increases (Pereira et al., 2002; Branco et al., 2000a, 2000b). The possible use of zooplankton to assess environmental conditions of the Imboassica lagoon was also investigated.

\section{Materials and Methods}

The Imboassica lagoon $\left(22^{\circ} 50^{\prime} \mathrm{S}\right.$ and $\left.44^{\circ} 42^{\prime} \mathrm{W}\right)$ is located on the southeast coast of Brazil, in the northern part of the State of Rio de Janeiro (Figure 1). The lagoon has a $3.26 \times 10^{6} \mathrm{~m}^{2}$ surface area, a $1.1 \mathrm{~m}$ mean and a $2.2 \mathrm{~m}$ maximum depth, a $3.56 \times 10^{6} \mathrm{~m}^{3}$ volume, $27.6 \mathrm{~km}$ perimeter, a $5.3 \mathrm{~km}$ maximum length, and a $1.3 \mathrm{~km}$ maximum width. It is separated from the sea by a $50 \mathrm{~m}$-wide sand bar, part of the surrounding area has been land-filled and is occupied by residential areas that drain their sewage into the lagoon. Its high surface/volume ratio favors the development of littoral aquatic macrophytes such as Typha domingensis, Eleocharis fistulosa and near the urban drainage Eichhornia crassipes. The climate of the region is warm-humid with a $23.5{ }^{\circ} \mathrm{C}$ average annual temperature. Rainfall is $800-1,200 \mathrm{~mm} . \mathrm{yr}^{-1}$, concentrated in the summer. Sometimes in the rainy season, due to the flooding of residential areas surrounding the lagoon, there is an artificial opening of the sand bar.

Rainfall and air temperature data were obtained from the meteorological station of the Pesagro/Macaé of the Instituto Nacional de Meteorologia. Samples were collected monthly from May, 1992, to December, 1995, at five stations located in different parts of the lagoon: I - near the sand bar; II - near the main sewage channel; III - in the center of the lagoon; IV - in the limnetic part in front of another residential area; and V - in the inner part. Water transparency, salinity, electric conductivity, temperature and $\mathrm{pH}$ were measured. Dissolved oxygen, total alkalinity, ammonium, nitrate, dissolved organic nitrogen, total organic nitrogen, suspended matter, dissolved and total phosphorus, orthophosphate, and silica were determined according to APHA (1992). Chlorophyll-a was determined spectrophotometrically after extraction with $90 \%$ ethanol at $80{ }^{\circ} \mathrm{C}$ according to Nusch and Palme (1975).

All zooplankton samplings were done using a $28 \mathrm{~cm}$ diameter and $68 \mu \mathrm{m}$ mesh plankton net. Three vertical hauls were made, each time filtering about $100 \mathrm{~L}$ of water. Samples were immediately fixed with $4 \%$ buffered formalin containing sucrose. Five 1-mL subsamples were counted in a Sedgewick-Rafter cell. The whole sample was inspected for rare species. Organisms were separated by species (holoplanktonic rotifers, cladocerans and copepods) or taxonomic groups (meroplanktonic and nectobenthonic forms).

The zooplankton was also collected some days after three artificial sand bar openings in 1992 and 1994 to check community changes. The spatial distribution of the zooplankton was recorded during an oligohaline condition on a day before a sand bar opening in May, 1995, and during a mesohaline condition, twenty-five days after a sand bar opening, in May, 1996. For the two spatial samplings, twenty collecting stations with distances of about $0.4 \mathrm{~km}$ from each other, in a regular grid, were previously plotted on the lagoon map. The stations were set using a Global Position System (GPS) for personal navigation. Samples were taken over a period of three hours in order to minimize temporal variations. Three replicate zooplankton samples were collected at each station. Limnological variables measured during the spatial distribution study were salinity, conductivity, water transparency, $\mathrm{pH}$, dissolved oxygen, and chlorophyll-a.

The frequency of occurrence for each taxon and abundance of taxa were recorded. Constant taxa were those present in $50 \%$ or more of the samples, common taxa were those with frequency between 10 and $49 \%$ and rare taxa present in less than $9 \%$ of the samples. In order to describe relations among environmental vari- 


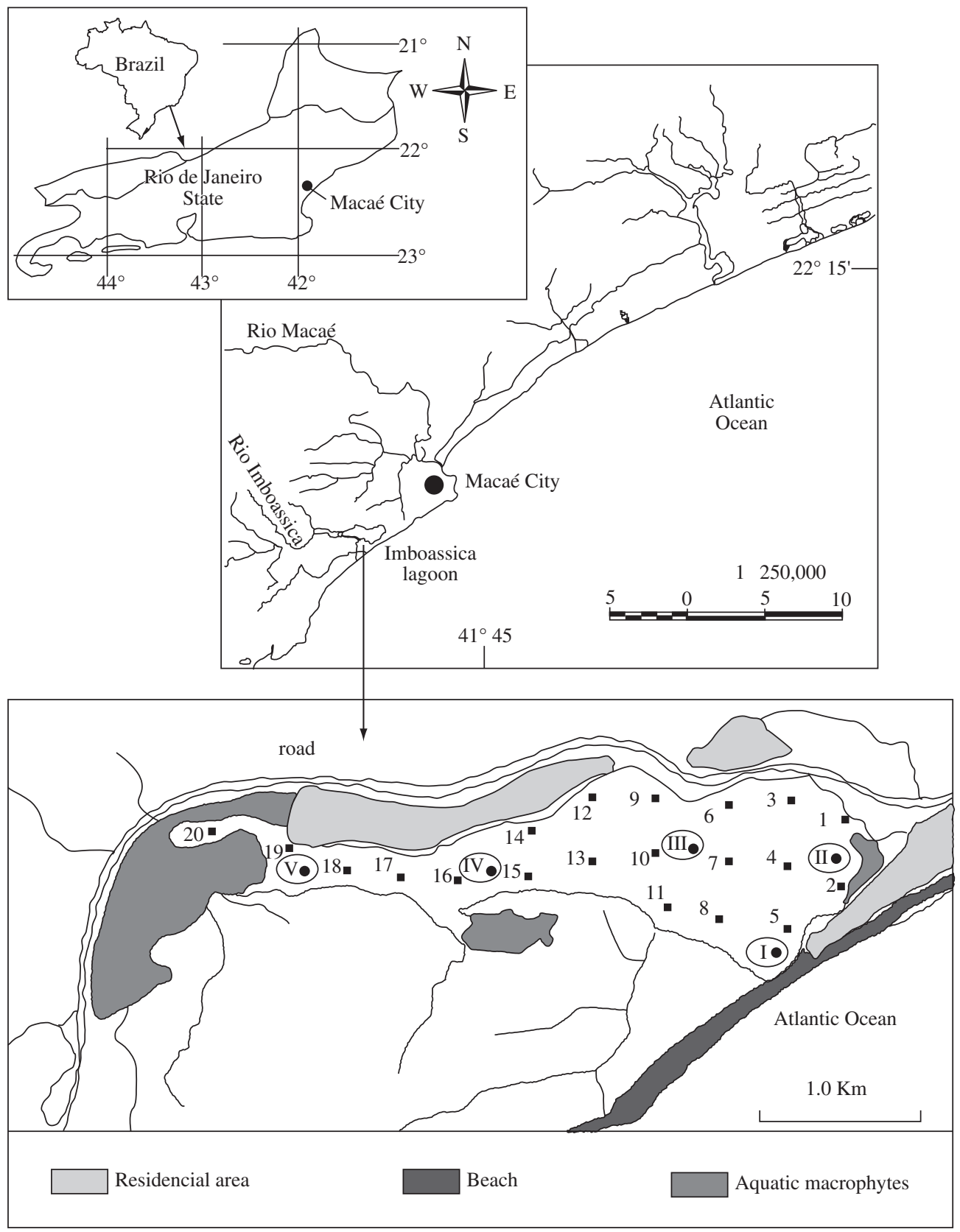

Figure 1. Imboassica Lagoon, indicating residential and aquatic macrophyte areas, the five monthly sampling stations in Roman numerals and the twenty sampling stations of the spatial distribution in Arabic numerals.

ables and the structure of the zooplankton community, Canonical Correspondence Analysis (CCA) was applied to all $\log$-transformed data, $\mathrm{x}^{\prime}=\log (\mathrm{x}+1)$, except $\mathrm{pH}$. CCA was carried out using a matrix data with thirteen of the seventeen environmental variables, the ones with high correlation among all data, and using a matrix with taxa considered constant and common. The Monte Carlo permutation test was carried out to test the significance of the environmental variables. Since 198 sample units were used in the CCA, only the physical and chemical variables and species scores were used to compose the CCA plot. Computer packages used were: STATISTICAvers. 4.2, and CANOCO - vers. 3.12.

\section{Results}

\subsection{The four-year study period: climate and the environment}

Monthly and maximum daily rainfall data and monthly air temperature average during the period of study (Figure 2) showed a rainy season beginning in 


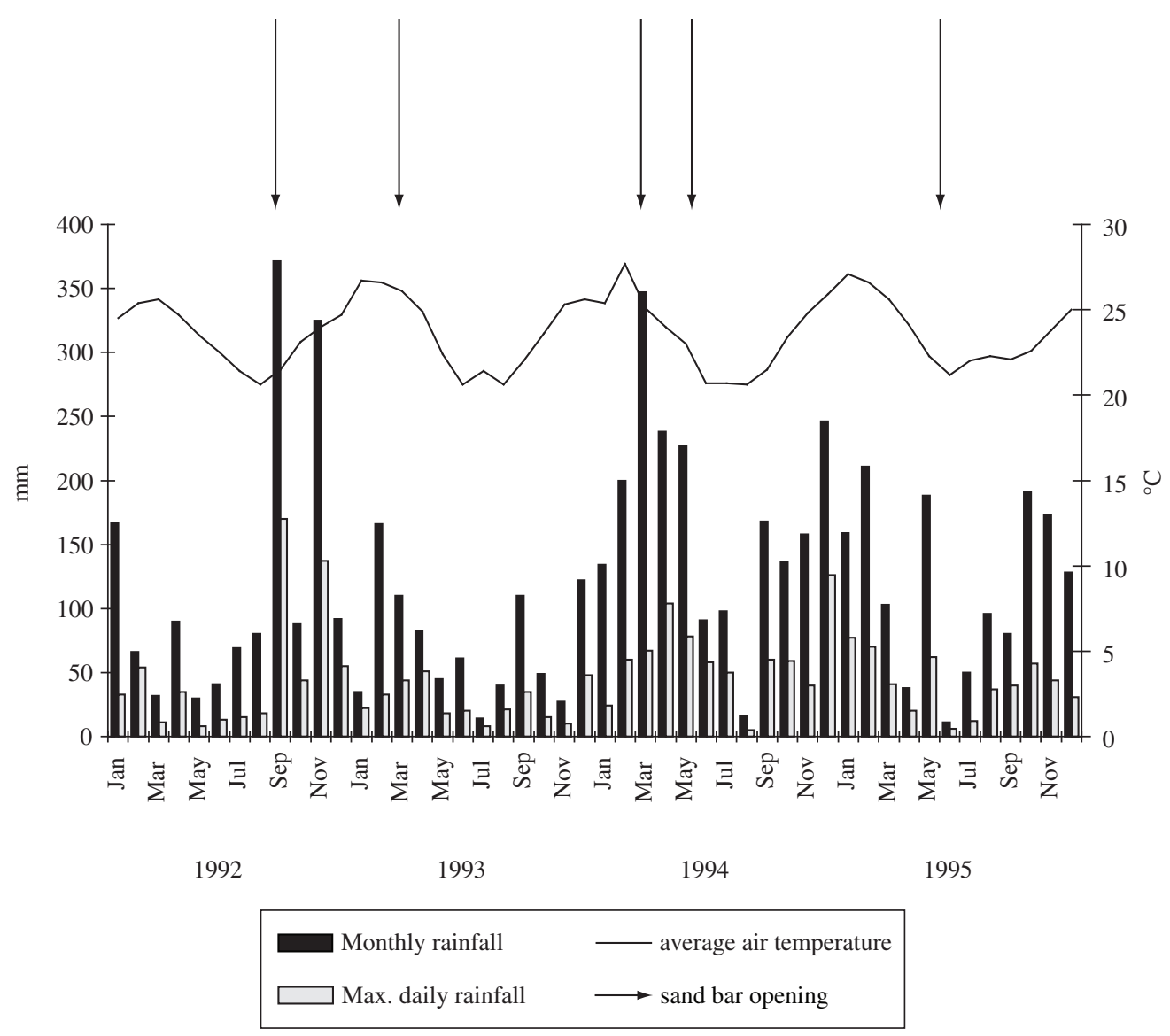

Figure 2. Total monthly and maximum monthly daily rainfall, monthly average air temperature and sand bar openings during the period of study.

September extending throughout the summer till March or May. The maximum daily rainfall was half or even more than two-thirds of the monthly rainfall in many months. There were five sand bar openings during the study period $\left(30^{\text {th }}\right.$ September, 1992, $3^{\text {rd }}$ March, 1993, $16^{\text {th }}$ March and $31^{\text {st }}$ May, 1994, and 29 $9^{\text {th }}$ May, 1995), most of which related to intense rainfalls.

The Imboassica lagoon presented low average values of transparency, total alkalinity, nitrate, ortophosphate, dissolved and total phosphorus, soluble reactive silica and chlorophyll-a (Table 1). The highest chlorophyll-a value was found at station II in August 1992, associated with a phytoplankton density increase. The salinity average pointed to an oligohaline system, but higher salinity values were generally detected at station I near the sand bar.

\subsection{The four-year study period: zooplankton community}

The zooplankton community was composed of 52 species of rotifers, 10 of cladocerans, and 13 of copepods including freshwater and marine taxa, freeliving and parasitic forms. There were also marine invertebrates, such as Appendicularia and Hydromedusae, and benthic Nematoda, Hydracarina and Ostracoda.
Polychaeta, Bivalvia, and Gastropoda larvae, Hexarthra spp., Lecane bulla, Synchaeta bicornis, cyclopoid, and calanoid nauplii were considered constant taxa in the community, 18 taxa were considered common, and all the others rare (Table 2).

Zooplankton richness was between 5 to 25 taxa per sample, with an average of 11 . Total zooplankton abundance ranged from 1,249 to $5,485,000$ individuals per cubic metre. The highest mean densities were attained by Brachionus plicatilis, Hexarthra spp., Synchaeta bicornis, cyclopoid nauplii, and Polychaeta, Bivalvia and Gastropoda larvae. Rotifer dominated in most sampling points except after the sand bar openings when larvae were the most abundant organisms. During the sand bar openings, due to the higher lagoon level in relation to the sea, initially almost all benthic and limnetic organisms were carried out to the sea. After this, in conformity with the tide, there was a passive inflow of marine organisms such as algae, invertebrate and fish larvae and an active inflow of adult fish. Freshwater and marine zooplankton were found together at moments just after the opening of the sand bar, the former in the surface layers and the latter in the bottom. According to the water conditions dur- 
Table 1. Mean value, standard deviation, minimum and maximum value and coefficient of variation of the physical and chemical variables during the period of study.

\begin{tabular}{lccccc}
\hline \multicolumn{1}{c}{ Variables } & $\begin{array}{c}\text { Average } \\
\text { value }\end{array}$ & $\begin{array}{c}\text { Standard } \\
\text { deviation }\end{array}$ & $\begin{array}{c}\text { Minimum } \\
\text { value }\end{array}$ & $\begin{array}{c}\text { Maximum } \\
\text { value }\end{array}$ & $\begin{array}{c}\text { Coefficient } \\
\text { of variation }\end{array}$ \\
\hline Temperature $\left({ }^{\circ} \mathrm{C}\right)$ & 24.9 & 2.86 & 18.10 & 31.10 & 0.11 \\
Transparency $(\mathrm{m})$ & 0.92 & 0.39 & 0.10 & 2.10 & 0.43 \\
$\mathrm{pH}$ & 7.53 & 0.66 & 5.73 & 9.37 & 0.09 \\
Conductivity $\left(\mathrm{mS} . \mathrm{cm}^{-1}\right)$ & 5.19 & 4.37 & 0.10 & 21.50 & 0.84 \\
Salinity $($ u.s. $)$ & 2.91 & 4.21 & 0.00 & 34.00 & 1.45 \\
Alkalinity $\left(\mathrm{mEq} . \mathrm{L}^{-1}\right)$ & 0.65 & 0.34 & 0.02 & 1.90 & 0.52 \\
Dissolved oxygen $\left(\mathrm{mg} . \mathrm{L}^{-1}\right)$ & 6.83 & 2.37 & 0.21 & 11.61 & 0.35 \\
Suspended matter $\left(\mathrm{g} . \mathrm{L}^{-1}\right)$ & 15.22 & 17.19 & 0.60 & 98.10 & 1.13 \\
Nitrate $\left(\mu \mathrm{g} . \mathrm{L}^{-1}\right)$ & 24.48 & 28.06 & 0.00 & 144.50 & 1.15 \\
Ammonium $\left(\mu \mathrm{g} . \mathrm{L}^{-1}\right)$ & 107.97 & 210.7 & 0.00 & $2,461.50$ & 1.95 \\
Dissolved organic nitrogen $\left(\mu \mathrm{g} . \mathrm{L}^{-1}\right)$ & 528.0 & 160.0 & 100.0 & $1,150.0$ & 0.30 \\
Total organic nitrogen $\left(\mu \mathrm{g} . \mathrm{L}^{-1}\right)$ & 658.0 & 190.0 & 140.0 & $1,560.0$ & 0.28 \\
Ortophosphate $\left(\mu \mathrm{g} . \mathrm{L}^{-1}\right)$ & 2.52 & 6.08 & 0.00 & 75.91 & 2.42 \\
Total P $\left(\mu \mathrm{g} . \mathrm{L}^{-1}\right)$ & 29.54 & 29.90 & 3.90 & 255.10 & 0.91 \\
Total dissolved-P $\left(\mu \mathrm{g} . \mathrm{L}^{-1}\right)$ & 12.96 & 9.14 & 0.00 & 101.15 & 0.71 \\
Soluble reativ silic $\left(\mathrm{mg} . \mathrm{L}^{-1}\right)$ & 4.08 & 3.24 & 0.20 & 33.80 & 0.79 \\
Chlorophyll-a $\left(\mu \mathrm{g} . \mathrm{L}^{-1}\right)$ & 9.51 & 13.87 & 0.40 & 142.19 & 1.46 \\
\hline
\end{tabular}

ing these events, marine organisms can either perish in the lagoon or live some weeks together with some euryhaline ones. Cladocerans or freshwater copepod species were not found while the sand bar remained open. A month after the closure of the sand bar, at salinity levels between 5-10\%o, Brachionus plicatilis, Lecane bulla, L. stenroosi, Synchaeta bicornis, S. baltica, Oithona spp., Acartia lilljeborgi, high density of gastropod and bivalve larvae were present at almost all sampling stations, and Hexarthra spp. were found only at the inner stations. Cladocerans were only found three to five months after the sand bar closure.

\subsection{The four-year study period: relation between the zooplankton community and other variables}

The four axes of the CCA accounted for $80 \%$ of total variability, and the first and the second axes for $63.7 \%$. The first axis consisted of a gradient of low to high values of conductivity, salinity, suspended matter, dissolved oxygen, ammonium, $\mathrm{pH}$, and silica, and a gradient of high-to-low water transparency and total nitrogen (Figure 3). The second axis comprised a gradient of high to low values of nitrate, salinity, conductivity, total phosphorus and another one of low to high values of total nitrogen, ammonium and dissolved oxygen. The left and right part of the CCA axes corresponded to marine and freshwater conditions, respectively. All zooplankton taxa, which presented high density during the periods of seawater inflow into the lagoon, were located at the left side of the biplot with cirripedia larvae and Oithona spp. plotted at the leftmost positions. The taxa found most in oligohaline and mesohaline conditions were plotted near the center of the biplot and the ones that were found only during freshwater conditions were located on the right part of the biplot.

\subsection{The spatial distribution study}

The average values of the water transparency, $\mathrm{pH}$ and chlorophyll-a were similar during oligohaline and mesohaline conditions (Table 3 ). The highest salinity and water conductivity values and corresponding high standard deviation were, however, detected during the mesohaline condition, when dissolved oxygen values were also higher.

The number of taxa per sample was between 13 and 20 during the oligohaline condition, and between 4 and 10 during the mesohaline. The zooplankton composition during the oligohaline condition was characterized by the dominance of Hexarthra fennica and by the presence of cladocerans at all twenty sampling stations (Figure 4). Sampling stations in the inner part of the lagoon $(18,19,20)$ presented low zooplankton density. Cladocerans, chironomid larvae, testate amoeba and nematods were present only during the oligohaline situation.

The zooplankton attained highest densities during the mesohaline condition, when calanoid nauplii, and gastropod and polychaet larvae were found at all sampling stations (Figure 5). Synchaeta baltica, Acartia lilljeborgi, Oithona oswaldocruzi and cirriped larvae were only present during this latter situation. The larvae group presented concentration above $1,000,000$ ind. $\mathrm{m}^{-3}$ at two sampling stations and lower density at the stations in the inner part of the lagoon. 
Table 2. Frequency of occurrence, mean and maximum density of the taxa during the period of study.

\begin{tabular}{|c|c|c|c|}
\hline Taxa & $\begin{array}{c}\text { Occur. } \\
(\%)\end{array}$ & $\begin{array}{c}\text { Density } \\
\text { mean }\end{array}$ & $\begin{array}{c}\text { Maximum } \\
\left(\text { ind.m }^{-3}\right)\end{array}$ \\
\hline \multicolumn{4}{|l|}{ ROTIFERS } \\
\hline Ascomorpha ecaudis & $<1$ & 7 & 1351 \\
\hline Asplanchna brightwelli & 2.1 & 5 & 452 \\
\hline Brachionus caudatus & 23 & 5651 & 134036 \\
\hline B.dolabratus & 3 & 8 & 738 \\
\hline B.falcatus & 6.5 & 1338 & 179064 \\
\hline B.havanensis & 5.6 & 5106 & 413354 \\
\hline B. plicatilis & 46 & 37093 & 4184000 \\
\hline B. quadridentatus & 1.3 & 6 & 1000 \\
\hline B.urceolaris & 1 & 3 & 482 \\
\hline Cephalodella forficata & 2.6 & 4 & 210 \\
\hline Collotheca campanulata & 1.7 & 6 & 510 \\
\hline Colurella uncinata & 1.7 & 6 & 690 \\
\hline Conochilus unicornis & 1.7 & 7 & 1131 \\
\hline Dipleuchlanis propatula & 10 & 10 & 890 \\
\hline Euchlanis incisa & 11.6 & 67 & 1353 \\
\hline Filinia pejleri & 10 & 558 & 30888 \\
\hline Gastropus minor & 1.3 & 27 & 2000 \\
\hline \multicolumn{4}{|l|}{ (H. fennica, H. mira) } \\
\hline K. cochlearis & 4 & 19 & 975 \\
\hline K. lenzi & 7 & 134 & 6547 \\
\hline K. tropica & 13.3 & 1858 & 88140 \\
\hline Lecane bulla & 76.3 & 2708 & 54601 \\
\hline L. cornuta & 1.7 & 7 & 523 \\
\hline L. curvicornis & 15.5 & 103 & 3000 \\
\hline L.elsa & $<1$ & 1 & 150 \\
\hline L. leontina & 5.1 & 20 & 580 \\
\hline L. monostyla & 1.3 & 1 & 90 \\
\hline L. papuana & 16 & 84 & 3636 \\
\hline L.proiecta & 1.3 & 8 & 806 \\
\hline L. pyriformis & 2.6 & 12 & 900 \\
\hline L. quadridentata & 1.3 & 3 & 337 \\
\hline L.signifera & 3 & 24 & 2000 \\
\hline L. spinulifera & 3 & 20 & 1000 \\
\hline L.stenroosi & 22 & 189 & 3396 \\
\hline Lepadella patella & 5.2 & 34 & 1600 \\
\hline Macrochaetus collinsi & 26.3 & 393 & 8400 \\
\hline Manfredium eudactylota & 13.8 & 624 & 55523 \\
\hline Monommata maculata & 2.6 & 9 & 445 \\
\hline Mytilina bisulcata & 2.6 & 2 & 270 \\
\hline Plationus patulus & 3.9 & 375 & 21104 \\
\hline Platyias leloupi & 1 & 10 & 1180 \\
\hline P. quadricornis & 9 & 37 & 1000 \\
\hline Polyarthra vulgaris & 21.5 & 2210 & 153000 \\
\hline Rotaria spp. & 2.6 & 17 & 905 \\
\hline Synchaeta baltica & 6.5 & 130 & 4684 \\
\hline S. bicornis & 50 & 23537 & 836000 \\
\hline Testudinella mucronata & 3 & 26 & 1311 \\
\hline Trichocerca bicristata & 3.9 & 33 & 1800 \\
\hline T. grandis & 8 & 36 & 3396 \\
\hline T. similis & 9 & 106 & 2375 \\
\hline T. stylata & 1 & 2 & 50 \\
\hline \multicolumn{4}{|l|}{ CLADOCERANS } \\
\hline Alona affinis & 7 & 56 & 120 \\
\hline Alona diaphana & 9 & 316 & 7000 \\
\hline
\end{tabular}

\begin{tabular}{|c|c|c|c|}
\hline Taxa & $\begin{array}{c}\text { Occur. } \\
(\%)\end{array}$ & $\begin{array}{c}\text { Density } \\
\text { mean }\end{array}$ & $\begin{array}{c}\text { Maximum } \\
\left(\text { ind. } m^{-3}\right)\end{array}$ \\
\hline Alona karua & 4.8 & 18 & 389 \\
\hline Bosminopsis deitersi & 7 & 79 & 3000 \\
\hline Ceriodaphnia cornuta & 3 & 18 & 540 \\
\hline Chydorus eurynotus & 8 & 50 & 720 \\
\hline Chydorus sphaericus & $<1$ & 10 & 1209 \\
\hline Diaphanosoma birgei & 5.2 & 61 & 2707 \\
\hline Ilyocryptus spinifer & 4 & 16 & 680 \\
\hline Moina minuta & 6.5 & 3782 & 322289 \\
\hline \multicolumn{4}{|c|}{ CYCLOPOID COPEPODS } \\
\hline Cyclopoid nauplii & 91.4 & 17504 & 276000 \\
\hline Cyclopoid copepodites & 56.4 & 1975 & 72602 \\
\hline Mesocyclops sp. & 2.1 & 31 & 1805 \\
\hline Microcyclops anceps & 6.5 & 150 & 4410 \\
\hline $\begin{array}{l}\text { Oithona spp. (O.hebes, } \\
\text { O. oswaldocruzi) }\end{array}$ & 11.6 & 2090 & 150000 \\
\hline $\begin{array}{l}\text { Thermocyclops } \\
\text { decipiens }\end{array}$ & 1.4 & 25 & 2300 \\
\hline Tropocyclops prasinus & 4.3 & 33 & 1000 \\
\hline \multicolumn{4}{|c|}{ PARASITIC CYCLOPOID } \\
\hline Ergasilus copepodites & 4.3 & 67 & 5405 \\
\hline \multicolumn{4}{|l|}{ CALANOID COPEPODS } \\
\hline Calanoid nauplii & 65.5 & 3072 & 46687 \\
\hline Calanoid copepodites & 35.3 & 1163 & 31024 \\
\hline $\begin{array}{l}\text { Marine calanoids } \\
\text { (Acartia lilljeborgi, A. } \\
\text { tonsa, } \\
\text { Paracalanus parvus, } \\
\text { Pseudodiaptomus } \\
\text { richardi) }\end{array}$ & 3.4 & 62 & 3650 \\
\hline \multicolumn{4}{|c|}{ HARPACTICOID COPEPODS } \\
\hline Harpacticoid nauplii & 8.2 & 471 & 30000 \\
\hline $\begin{array}{l}\text { Harpacticoid } \\
\text { copepodites }\end{array}$ & 1 & 10 & 608 \\
\hline $\begin{array}{l}\text { Harpacticoids } \\
\text { (Euterpina acutifrons, } \\
\text { Cletocamptus deitersi) }\end{array}$ & 13.8 & 115 & 3000 \\
\hline \multicolumn{4}{|l|}{ OTHERS } \\
\hline Tecamoeba & 9 & 270 & 812 \\
\hline $\begin{array}{l}\text { Appendicularia } \\
\text { (Oikopleura longi- } \\
\text { cauda) }\end{array}$ & 11.6 & 89 & 3005 \\
\hline $\begin{array}{l}\text { Hydromedusa } \\
\text { (Zanclea costata) }\end{array}$ & 1.3 & 16 & 1020 \\
\hline Nematoda & 2.6 & 24 & 2142 \\
\hline Hydracarina & 1.3 & 250 & 30000 \\
\hline Ostracoda & 13.1 & 376 & 40000 \\
\hline \multicolumn{4}{|l|}{ LARVAE } \\
\hline Chaoboridae larvae & 2.6 & 6 & 350 \\
\hline Chironomidae larvae & 12.5 & 66 & 1612 \\
\hline Cirripedia larvae & 25 & 1546 & 28000 \\
\hline Polychaeta larvae & 68.5 & 17360 & 1251000 \\
\hline Bivalvia larvae & 65 & 20466 & 489130 \\
\hline Gastropoda larvae & 79.3 & 58838 & 3552489 \\
\hline Malacostraca nauplii & 3.4 & 1186 & 52000 \\
\hline Malacostraca zoeas & $<1$ & 1 & 111 \\
\hline Fish larvae & $<1$ & 1 & 145 \\
\hline
\end{tabular}




\section{Discussion}

\subsection{The four-year study period: climate and the environment}

There was a strong influence of the weather conditions on the Imboassica lagoon water level during the entire study period. Marked short-term meteorological changes due to the passage of polar fronts resulted in temperature decrease and intense rainfall. This, in turn, caused a rise in the level of the lagoon and the sand bar opening due to flooding of the urban area. The importance of the passage of polar fronts on the dynamics of aquatic ecosystems in the Southeast part of Brazil has already been recognized by Tundisi et al. (2004), and according to Costa-Moreira and Carmouze (1991), these events produce strong vertical mixing, and can induce marine water intrusions in some lagoons of the region.

Despite the sewage inflow, the nutrients and chlorophyll-a levels in the Imboassica lagoon were low to a presumed eutrophic environment. Our results indicated that with the sand opening, there is a loss of total organic nitrogen and an increase of total phosphorus due to seawater input. This latter fact has already been demonstrated in brackish shallow lakes (Jeppesen et al., 1998) and could be explained by the release of ironbound phosphorus from sediments due to $\mathrm{FeS}$ formation during seawater influence. In addition, the dredging of the inner littoral aquatic macrophyte area, and the negative influence of salinity on these plants could also have contributed to the rise of inorganic nutrients and suspended matter in the lagoon during the sand bar openings. Aquatic macrophytes of the littoral zone of Imboassica lagoon may effectively contribute to the storage of nutrients in this area. For instance, the dominant macrophyte Typha domingensis tends to build up phosphorus while alive, releasing it actively or passively during senescence (Furtado, 1998). While the sand bar remained open, a rise in suspended matter and ammonium values was also evident, and was probably associated with the low level of the lagoon, increasing the influence of sediments on the water column and lowering the dilution of the sewage coming from the urban channels, respectively.

Low water transparency, permanent water circulation, and a great biomass of macrophytes limit light and nutrient utilization by phytoplankton and, as consequence, may explain the generally low concentration of chlorophyll-a. This picture described above was summarized in our CCA results. Besides the left and right parts of the CCA biplot corresponding to marine and freshwater conditions respectively, the quadrants of the plot can be associated with most specific environmental conditions. The quadrant conductivity, salinity, $\mathrm{pH}$, total phosphorus and nitrate arrows can be explained as the sand bar opening situation. In the opposite quadrant, the op-

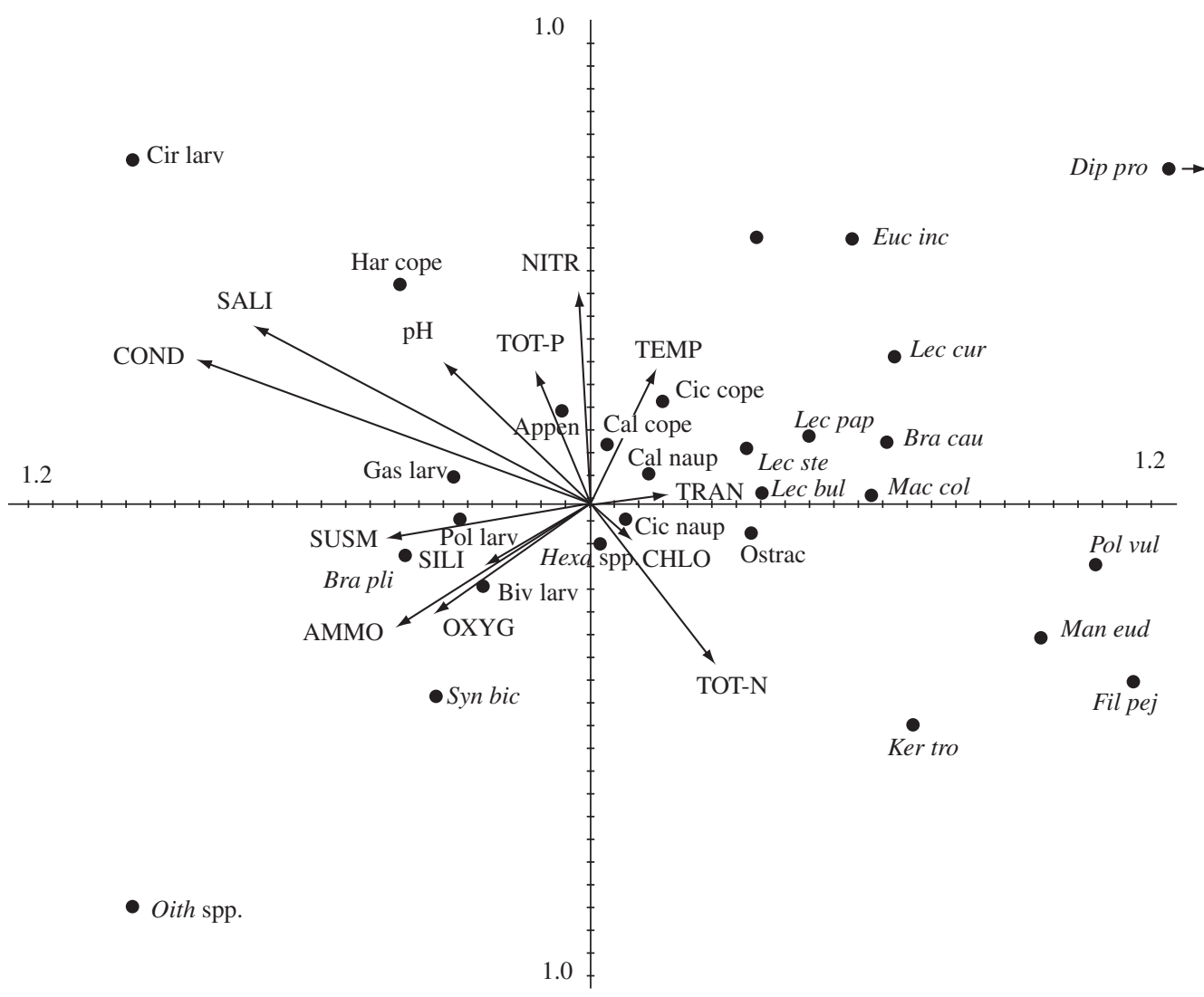

Figure 3. CCA biplot of constant and common taxa (points) and limnological variables (arrows). 
Table 3. Mean value, standard deviation, minimum and maximum physical and chemical variable values during the spatial sampling in oligohaline and mesohaline conditions.

\begin{tabular}{|c|c|c|}
\hline Variables & Oligohaline & Mesohaline \\
\hline \multicolumn{3}{|l|}{ Transparency (m) } \\
\hline Average & 0.68 & 0.58 \\
\hline Standard deviation & 0.22 & 0.15 \\
\hline Minimum & 0.20 & 0.25 \\
\hline Maximum & 1.00 & 0.95 \\
\hline \multicolumn{3}{|l|}{$\mathrm{pH}$} \\
\hline Average & 7.54 & 7.42 \\
\hline Standard deviation & 0.52 & 0.28 \\
\hline Minimum & 5.95 & 6.91 \\
\hline Maximum & 7.94 & 7.81 \\
\hline \multicolumn{3}{|l|}{ Conductivity $\left(\mathrm{mS} . \mathrm{cm}^{-2}\right)$} \\
\hline Average & 2.20 & 22.23 \\
\hline Standard deviation & 0.70 & 2.84 \\
\hline Minimum & 0.24 & 16.64 \\
\hline Maximum & 3.15 & 28.00 \\
\hline \multicolumn{3}{|l|}{ Salinity (U.S.) } \\
\hline Average & 1.52 & 14.71 \\
\hline Standard deviation & 0.47 & 2.08 \\
\hline Minimum & 0.16 & 11.67 \\
\hline Maximum & 1.97 & 18.25 \\
\hline \multicolumn{3}{|c|}{ Dissolved oxygen (mg.L $\left.\mathrm{L}^{-1}\right)$} \\
\hline Average & 6.56 & 7.51 \\
\hline Standard deviation & 1.50 & 1.11 \\
\hline Minimum & 3.80 & 5.00 \\
\hline Maximum & 9.13 & 9.92 \\
\hline \multicolumn{3}{|l|}{ Chlorophyll-a $\left(\mu \mathrm{g} . \mathrm{L}^{-1}\right)$} \\
\hline Average & 4.60 & 4.99 \\
\hline Standard deviation & 1.45 & 1.11 \\
\hline Minimum & 2.70 & 2.92 \\
\hline Maximum & 8.57 & 6.94 \\
\hline
\end{tabular}

posite situation, the sand bar is closed and higher values of total nitrogen and chlorophyll-a are registered during the freshwater environment. The quadrant ammonium, suspended matter, dissolved oxygen and silica arrows can be associated with both sand bar opening and vertical mixing by wind influence. The opposite quadrant, high values of temperature and water transparency can be explained as corresponding to water column stability.

\subsection{The four-year study period: relation between the zooplankton community and other variables}

Taking into account disturbance as any relatively discrete event in time that removes organisms and opens up space or other resources (Townsend, 1991) we can consider the sand bar opening as a disturbance on the Imboassica lagoon ecosystem. Besides causing changes in planktonic communities (e.g. Mello and Suzuki, 1998; Panosso and Esteves, 2000; Kozlowsky-Suzuki and Bozelli, 2004), the
Rotifers

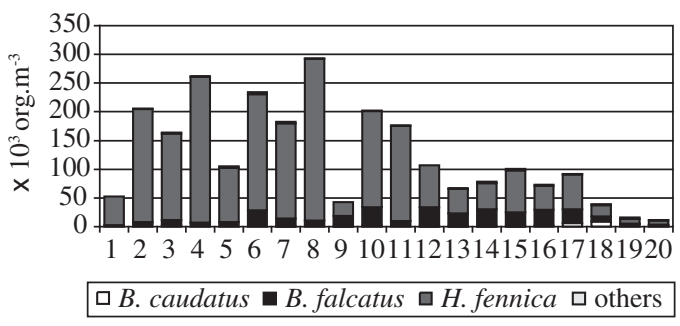

Copepods

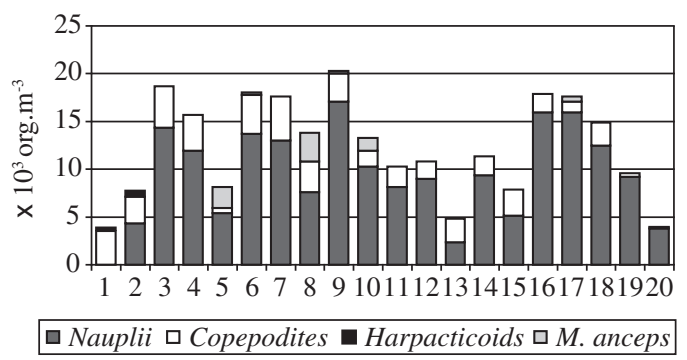

Cladocerans

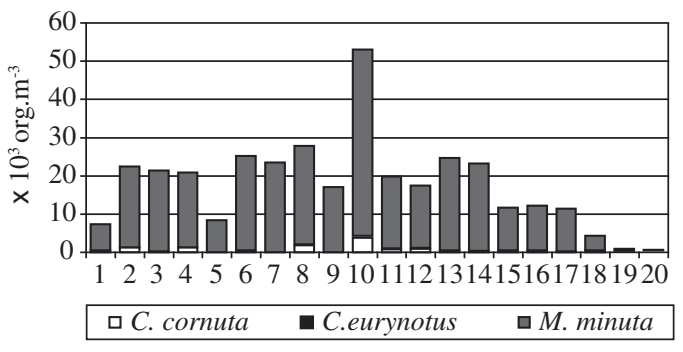

Larvae

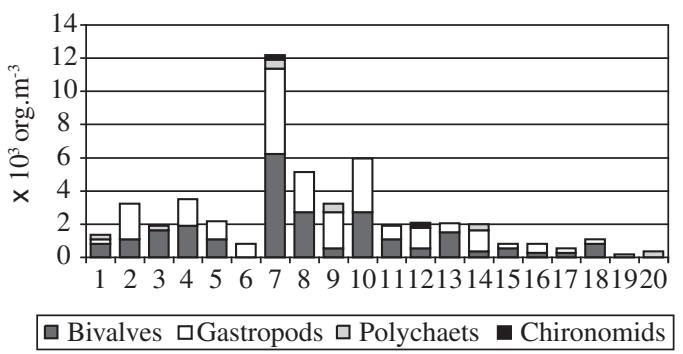

Figure 4. Density of main zooplankton taxa at the 20 sampling points during the oligohaline condition.

sand bar opening also affects other aquatic communities. For instance, most of the benthic community died during the sand bar openings, with the surviving taxa being those living deep in the sediments, either capable of staying buried, or which were not exposed (Gonçalves et al., 1998). The rich periphytic community of the Imboassica lagoon is also highly altered by the sand bar opening due to aquatic macrophyte death, which caused increase of detritus and nutrient concentration (Fernandes, 1998). 

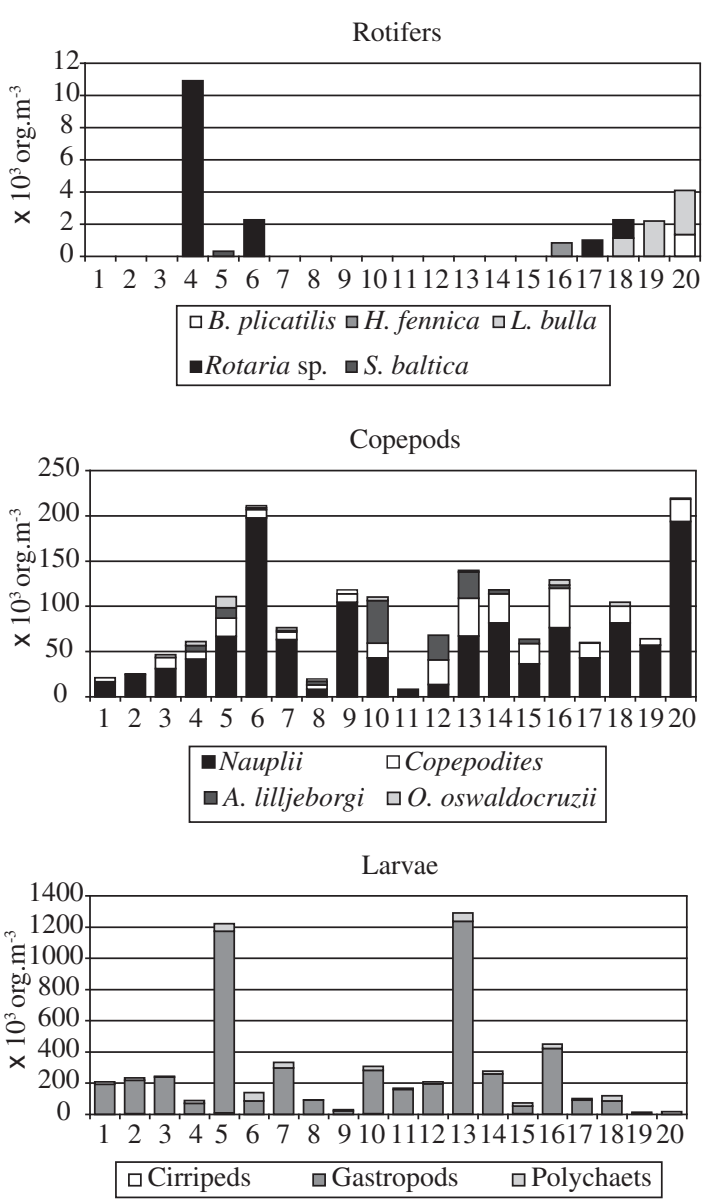

Figure 5. Density of main zooplankton taxa at the 20 sampling points during the mesohaline condition.

These plants may perish in a larger or smaller area as a consequence of the sand bar opening, and have their development impaired by the seawater entrance. During these events the structure of the fish community is affected with the dominance $(81 \%)$ of marine species in the lagoon (Aguiaro and Caramaschi, 1995).

Notwithstanding the direct marine influence during sand bar openings, the low average value of salinity characterized Imboassica lagoon as an oligohaline environment. The occurrence of the mesohaline condition many times near the sand bar and the artificial openings influenced the zooplankton composition directly. Most of the constant and common zooplankton taxa found in the Imboassica lagoon had previously been observed in brackish or seawater. Brachionus plicatilis, Hexarthra fennica, H. intermedia, Keratella cochlearis, K. tropica, Synchaeta bicornis have been distinguished as typical lagoonal and euryaline species in some marine-influenced lagoons of the State of Rio de Janeiro (Arcifa et al., 1994; Branco et al., 2000b). Dipleuchlanis propatula, Lecane bulla, L. curvicornis, L. papuana, L. stenroosi, L. quadridentata, Macrochaetus collinsi, Polyarthra vulgaris were previously found among estuarine zoo- plankters (Neumann-Leitão et al., 1992).

The species associated with high salinity in the Imboassica lagoon are commonly detected along the southeast coast of Brazil. Valentin and Monteiro-Ribas (1993) found the appendicularian Oikopleura longicauda distributed in a nucleus of more than 100 ind. $\mathrm{m}^{-3}$ between the shore and the shelf break at 20-22 ${ }^{\circ} \mathrm{S}$. Acartia lilljeborgi, Pseudodiaptomus richardi, Oithona hebes and Euterpina acutifrons were found as the most numerous and frequent species in Brazilian river estuaries by Lansac-Tôha and Lima (1993).

According to our results, cirriped larvae, Oithona spp., and marine calanoid copepods can be suggested as indicators of recent seawater inflow in the Imboassica lagoon. Higher density of gastropod larvae, Brachionus plicatilis, Synchaeta bicornis or S. baltica revealed signs of marine influence after the closing of the sand bar. These taxa can also be related to a critical boundary between freshwater and marine waters when low species richness was present and some meroplankters such as polychaet and bivalve larvae seemed to be common. The density increase of veligers of Heleobia australis was one of the most notable facts caused by the sand bar openings. The population of this dominant gastropod in the benthic macroinvertebrate community of the Imboassica lagoon (Gonçalves et al., 1998) had its larvae number increased after each sand bar opening. Adults of $H$. australis are furthermore probably capable of penetrating into the sediment and are not washed out with the openings. The position of gastropod larvae in the CCA plot indicates high densities in mesohaline conditions, the same being true for polychaet and bivalve larvae, S. bicornis, and Brachionus plicatilis.

A great abundance of cladocerans and a high rotifer richness indicated an oligohaline-to-freshwater environment in the Imboassica lagoon. The increase in the number of rotifer species during the freshwater situation contributed to the highest zooplankton community richness. Polyarthra vulgaris, Filinia pejleri, Manfredium eudactylota and Dipleuchlanis propatula were the constant rotifers most associated with freshwater conditions. Some of the most frequently observed taxa, such as Hexarthra spp., Lecane bulla, copepod nauplii, showed a fast density recovery after seawater inflow.

The sand bar opening, wind influence on shallow water, and macrophyte colonization can be pointed to, in decreasing order, as the main factors acting on the zooplankton community of the Imboassica lagoon. However, trophic interactions in the lagoon environment, such as food availability and grazing pressure, all linked to the factors mentioned above, can also be suggested as responsible for zooplankton community features.

The low level of chlorophyll-a pointed to a low phytoplankton availability and/or to an intense herbivory pressure on greazable algae, which can limit the populations of large nanoplankton specialists. Besides microalgae, detritus and bacteria may constitute important food for the aquatic community in a shallow environ- 
ment influenced by aquatic macrophyte colonization and input of drainage such as in the Imboassica lagoon. This picture benefits rotifer occurrence since detrital particles and bacteria are known to be important dietary constituents for many of them.

All freshwater fish feed on zooplankton in a broad sense at some stage in their life and it is generally accepted that the first food of the post larval fish consists at least partially of zooplankton, including the early stages of piscivorous and carnivorous fishes. Aguiaro and Caramaschi (1998), analyzing the trophic guild of the fish assemblage in Imboassica lagoon, have found, among the 12 dominant species, 5 microphagous carnivores, which consumed cladocerans, copepods, and chironomid larvae, and 4 omnivores, which ingested cladocerans and chironomid larvae. According to these authors, rotifers were present only in the diet of Platanichthys platana, one of the microphagous carnivores, which shows the direct influence of fish feeding habits on the zooplankton community, favoring smaller zooplankters.

\subsection{The horizontal distribution study}

The few studies dealing with zooplankton spatial distribution in coastal lagoons have stressed the importance of the gradient of salinity on taxa distribution (LamHoai and Amanieu, 1989; Lam-Hoai, 1991). They also highlighted the instability of their spatial and temporal features, related to water movement under the effects of tides and winds. Unfortunately, the distribution of plankton populations is not easily described, since it may reflect, besides the passive or wind dispersion, conflicting responses to environmental conditions or to irregularlydistributed food sources, and grazing pressure.

Distinct zooplankton communities were found during the two spatial surveys in the Imboassica lagoon. Both displayed the presence of copepod nauplii and meroplanktonic forms at most of the sampling stations and a zooplankton abundance decrease at the inner sampling stations. In addition, changes in zooplankton species richness and density in the surveys indicated the influence of the input of the major urban channels at sampling stations 1 and 9, and inner tributaries, probably through water transparency reduction due to nutrient and sediment discharge.

The most notable difference between the oligohaline and the mesohaline zooplankton communities was the presence of cladocerans at all sampling stations in the first condition. In addition, taxa considered rare along the four years of study, such as Brachionus falcatus, Moina minuta and Ceriodaphnia cornuta, were dominant in terms of abundance in the oligohaline condition.

Although the distribution of zooplankton may be related to wind-induced water movements, the formation of micro-aggregations by cladocerans related to environmental conditions has been suggested by George (1974). M. minuta and C. cornuta showed aggregation during the oligohaline condition at sampling station 10 in the deepest part of the lagoon and where the water transparency was the highest. Conversely, there was a decrease in M. minuta abundance near the sand bar (station 5), probably related to the influence of salinity. Decreases in M. minuta density were also observed at station 1, 18, 19 and 20 , where the low water transparency due to drainage inputs certainly impaired all filter feeding zooplankters. On the other hand, emphasis must be given to a high predation pressure suffered by this species as a consequence of its globular shape and regular locomotion.

Different from cladocerans, rotifers are believed to have a great capacity for passive dispersal. This can explain their presence at all stations in oligohaline conditions when Hexarthra fennica attained the highest density and was present at all sampling stations together with Brachionus falcatus, which was considered rare along the four years of study.

The zooplankton community of the mesohaline environment was characterized by the highest density of gastropod larvae, especially at the station near the sand bar and in the central area of the lagoon, where the benthic community attains its highest density. This does not agree with a passive dispersion of veligers larvae, and, despite the higher wind influence during the mesohaline samplings, a high concentration of larvae was probably associated with meroplankton recruitment from nearby areas.

\section{Conclusions}

The main environmental change in Imboassica lagoon was related to the artificial sand bar openings, and zooplankton constituted a sensitive tool for monitoring such changes. Some of the most successful zooplankton populations in the lagoon were either favored by the disturbance of the sand bar opening, such as the veligers of the gastropod Heleobia australis, or capable of fast recovery after the closing of the sand bar, during the transition from a marine into an oligohaline environment, such as Hexarthra spp.. These populations seemed well-adapted to the conditions usually found in the lagoon, such as drastic osmotic changes, frequent column mixing, nutrient input, and high fish predation pressure. These prevailing conditions may challenge the maintenance of cladocerans such as Moina minuta, which occasionally displays population increases under favorable conditions of low marine influence.

\section{References}

AGUIARO, T. and CARAMASCHI, EP., 1995. Ichthyofauna composition of three coastal lagoons in the north of the State of Rio de Janeiro (Brazil). Arquivos de Biologia e Tecnologia, vol. 38 , no. $4,1181-1189$.

AGUIARO, T. and CARAMASCHI, EP., 1998. Trophic guilds in fish assemblages in three coastal lagoons of Rio de Janeiro State (Brazil). Verh. Internat. Verein. Limnol., vol. 26, no. 5, p. 2166-2169.

APHA, American Public Health Association, 1992. Standard Methods for the Examination of Water and Wastewater. Washington, D.C., 1268 p. 
ARCIFA, MS., CASTILHO, MSM. and CARMOUZE, JP., 1994, Composition et évolution du zooplancton dans une lagune tropicale (Brésil) au cours d'une période marquée par une mortalité de poissons. Rev. Hydrobiol. trop., vol. 27, no. 3, p. 251-263.

BRANCO, CWC., ESTEVES, FA. and KOZLOWSKYSUZUKI, B., 2000a. The zooplankton and other limnological features of a humic coastal lagoon (Lagoa Comprida, Macaé, RJ) in Brazil. Hydrobiologia, vol. 437, p. 71-81.

BRANCO, CWC., KOZLOWSKY-SUZUKI, B., ESTEVES, FA. and SOUZA, LC., 2000. Rotifers as ecological indicators in three coastal lagoons in the State of Rio de Janeiro. Anais do V Simpósio de Ecossistemas Brasileiros: Conservação. Anais... Vitória, ES, vol. II, p. 429-448.

COSTA-MOREIRA, AL. and CARMOUZE, JP., 1991. La lagune de Saquarema (Brésil): hydroclimat, seston et éléments biogéniques au cours d'un cycle annuel. Rev. Hydrobiol. Trop., vol. 24 , no. 1, p. 13-23.

FERNANDES, VO., 1998. Variação temporal e espacial na composição da comunidade perifítica na lagoa Imboassica. In: ESTEVES, FA., ed., Ecologia das Lagoas Costeiras do Parque Nacional da Restinga de Jurubatiba e do Município de Macaé Rio de Janeiro, NUPEM, p. 221-236.

FURTADO, ALS., 1998. Ash free dry weight, organic carbon, nitrogen and phosphorus content of Typha domingensis (Thyphaceae), an aquatic macrophyte. Verh. Internat. Verein. Limnol., vol. 26, no. 4, p. 1842-1845.

GEORGE, DG., 1974. Dispersion patterns in the zooplankton populations of a eutrophic reservoir. Journ. of An. Ecol., vol. 43 , no. 2 , p. $537-551$.

GONÇALVES, JFJR., FONSECA, JJL. and CALLISTO, MFP., 1998. Population dynamics of Heleobia australis (Gastropoda) in a coastal lagoons (Rio de Janeiro, Brazil). Verh. Internat. Verein. Limnol., vol. 26, no. 4, p. 2056-2057.

JEPPESEN, E., SØNDERGAARD, M., JENSEN, JP, KANSTRUP, E. and PETERSEN, B., 1998. Macrophytes and turbidity in brackish lakes with special emphasis on the role of top-down control. In JEPPESEN, E., SONDERGAARD, MA., SONDERGAARD, MO. and CHRISTOFFERSEN, K. (eds), The structuring role of submerged macrophytes in lakes. Ecological Studies. Springer Verlag., vol. 131, p. 91-114.

KOZLOWSKY-SUZUKI, B. and BOZELLI, RL., 2004. Resilience of a zooplankton community subjected to marine intrusion in a tropical coastal lagoon. Hydrobiologia, vol. 522, p. 165-177.

LAM-HOAI, T., 1991, Zooplankton counted by image analysis and size-frequency distribution in a coastal lagoon. Arch. Hydrobiol., vol. 121, no. 2, p. 147-159.

LAM-HOAI, T. and AMANIEU, M., 1989. Structures spatiales et évolution saisonnière du zooplancton superficiel dans deux écosystèmes lagunaires nord-méditerranéens. Ocean. Acta., vol. 12, no. 1, p. 65-77.

LANSAC-TÔHA, FA. and LIMA, AF., 1993. Ecologia do zooplâncton do estuário do Rio Una do Prelado (São Paulo, Brasil). Acta Limnol. Brasil, vol. VI, p. 82-96.

MELLO, S. and SUZUKI, MS., 1998. Variações temporais do fitoplâncton das lagoas Imboassica, Cabiúnas e Comprida. In: ESTEVES FA, ed., Ecologia das Lagoas Costeiras do Parque Nacional da Restinga de Jurubatiba e do Município de Macaé Rio de Janeiro, NUPEM. p. 177-203.

NEUMANN-LEITÃO, S., PARANAGUÁ, MN. and VALENTIN, JL., 1992. The planktonic rotifers of the estuarine lagunar complex of Suape (Pernambuco, Brazil). Hydrobiologia, vol. 232 , p. $133-143$.

NEWTON, A., ICELY, JD., FALCÃO, M., NOBRE, A., NUNES, JP., FERREIRA, JG., and VALE, C., 2003. Evaluation of eutrophication in the Ria Formosa coastal lagoon, Portugal. Continental Shelf Research, vol. 23, p. 1945-1961.

NUSCH, EA. and PALME, G., 1975. Biologische Methoden für die Praxis der Gewässeruntersuchung. GWF - Wasser/ Abwasser, vol. 116, p. 562-565.

PANOSSO, R. and ESTEVES, FA., 2000. Effects of disturbance on phosphorus turnover and plankton dynamics. Journal of Plankton Research, vol. 22, no. 3, p. 589-595.

PEREIRA, R., SOARES, AMVM., RIBEIRO, R. and GONÇALVES, F., 2002. Assessing the trophic state of Linhos lake: a first step towards ecological rehabilitation. Jour. Environm. Management, vol. 64, no. 3, p. 285-297.

SUZUKI, MS., FIGUEIREDO, RO., CASTRO, SC., SILVA, CF., PEREIRA, EA., SILVA, JA. and ARAGON, GT., 2002. Sand bar opening in a coastal lagoon (Iquipari) in the Northern region of Rio de Janeiro State: hydrological and hydrochemical changes. Braz. Jour. of Biol., vol. 62, no. 1, p. 51-62.

TOWNSEND, CR., 1991. Community organization in marine and freshwater environments. In: BARNES, RKS. and MANN, KH. (eds). Fundamentals of Aquatic Ecology. Blackwell Scientific Publications, Oxford, p. 125-144.

TUNDISI, JG., MATSUMURA-TUNDISI, T., ARANTES JÚNIOR, JD., TUNDISI, JEM., MANZINI, NF. and DUCROT, R., 2004. The response of Carlos Botelho (Lobo, Broa) reservoir to the passage of cold fronts as reflected by physical, chemical, and biological variables. Braz. Journ. of Biol., vol. 64, no. 1, p. 177-186.

VALENTIN, JL. and MONTEIRO-RIBAS, WM., 1993. Zooplankton community structure on the east-southeast Brazilian continental shelf $\left(18-23^{\circ} \mathrm{S}\right.$ latitude). Continental Shelf Res., vol. 13, no. 4, p. 407-424. 
Branco, CWC., Kozlowsky-Suzuki, B. and Esteves, FA. 